\title{
BLOOD-DERIVED, TISSUE ENGINEERING BIOMATERIALS
}

\author{
THIERRY BURNOUF
}

Human Plasma Product Research Services (HPPS), France

\begin{abstract}
Fibrin sealant and platelet gels are human blood-derived, biodegradable, non toxic, surgical products obtained by mixing a fibrinogen concentrate or a platelet rich plasma with thrombin, respectively. Fibrin sealant is now a well known surgical tool increasingly used to stop or control bleeding. or to provide air and fluid tightness in many surgical situations. Platelet gels are newly developed preparations that are of specific interest because they contain numerous physiological growth factors and cytikines that are released upon the activation of blood platelets by thrombin. These growth factors, including PDGF, TGF- $\beta 1, B M P$, and VEGF have been shown to stimulate cell growth and differentiation with special clinical benefits for soft and bony tissue healing and regeneration. Platelet gels allow surgeons to manipulate the cellular environment of surgical sites and to guide tissue regeneration. A specific interest of such products is observed for the induction of osteogenesis and chondrogenesis. Advances in the preparation. clinical use, and safety of these two important classes of blood-derived biomaterials are reviewed.
\end{abstract}

Biomed Eng Appl Basis Comm, 2004(December); 16: 294-304.

Keywords: platelet gel, fibrin sealant, growth factors, thrombin

\section{INTRODUCTION}

Topical haemostatic products, made from human blood and plasma, are biomaterials increasingly used in surgery because of their unique biological and physiological advantages compared to synthetic sealants [1-3]. They not only possess tissue sealing and hemostatic properties but, when containing plateletderived growth factors (GF), they may also stimulate cell growth and differentiation [4]. One of their advantages, compared to synthetic glues and other biomaterials, is their physiological compatibility with human tissues, which does not cause tissue necrosis or other body reactions, permits colonization by cells and

Received: Apr 16, 2004; Accepted: Oct 10, 2004

Correspondence:Thierry Burnouf, Professor

HPPS, 18 rue Saint-Jacques, 59000 Lille,

France

E-mail: tburnou@attglobal.net full biodegradability by body's enzymes in a matter of days to weeks. Increasingly, these blood derived biomaterials are also used as tissue engineering tools, therefore allowing surgeons to manipulate and improve, in vitro as in vivo, the cellular environment to promote the success of soft and hard tissue grafting and regeneration. This review describes the biomaterials produced from human blood and highlights the differences in their biochemical and physiological properties and clinical applications. A special emphasis is put on platelet gel (PG) which is a newer development in this field, of specific interest for cell engineering applications.

\section{FIBRIN SEALANTS}

\subsection{Definition}

Fibrin sealants (FS) are also known as fibrin glues or fibrin adhesives. They are obtained by mixing a concentrated plasma derived fibrinogen-rich fraction 
made from human plasma, with a concentrate of thrombin. Mixing both components mimics the physiological reaction of fibrino-formation as it occurs in the blood circulation during the last step of the coagulation cascade, when fibrinogen polymerizes into fibrin to achieve hemostasis. This physiological reaction, illustrated in the figure, takes place in the presence of calcium ions and leads to the formation of a rigid and elastic fibrin clot. In clinical and surgical setting, the fibrin clot consolidates and adheres to the application site in a matter of a few seconds. Various types of applicators have been developed to best suit the clinical needs [5]. The fibrinogen concentrate may also contain other plasma proteins such as fibronectin and factor XIII, depending upon the preparation method used [3]. Some fibrinogen preparation are solubilized with aprotinin, a fibrinolytic inhibitor, and thombin is formumated with a calcium chloride solution. When both components are mixed, FS acts as a fluid-tight sealing agent enabling, thanks to its physical and rheological properties[6], to stop bleeding and/or to seal tissues and surgical materials, such as graft, in a desired configuration $[1-3,7]$.

\subsection{Mode of Preparation}

The components of FS can be prepared from large pools of plasma or from single plasma donations; respective preparations are then usually known as "commercial" and "blood-bank" FS, respectively.

In commercial FS, the fibrinogen concentrate is made by an industrial fractionation process of batches of hundreds or thousands of litres of plasma, following a general procedure also performed to prepare other therapeutic plasma products, like coagulation factors VIII, IX, albumin, and immunoglobulins [8]. The fibrinogen concentrate is usually obtained by precipitation methods from cryoprecipitate (obtained by thawing plasma at $1-3^{\circ} \mathrm{C}$ ) or Cohn fraction I (obtained by $8-10 \%$ cold ethanol precipitation) [9]. The fibrinogen fraction undergoes further purification, viral reduction, concentration steps, aseptic filtration, aseptic filling, and freeze-drying [9]. The resulting concentrate has high protein content (typically more than $80 \mathrm{~g} / 1$ in fibrinogen) and may contain fibronectin, von Willebrand factor, and Factor XIII [3, 9]. Thrombin is usually obtained by activation of a prepurified human prothrombin (factor II) fraction (similar to the prothrombin complex concentrate) followed by chromatographic purification, concentration, aseptic filtration, aseptic filling, and freeze-drying. The concentration of the thrombin concentrate is usually $500-1000 \mathrm{UNIH} / \mathrm{ml}$, although lower potency products (less than $10 \mathrm{UNIH} / \mathrm{ml}$ ) are also available when a slower clotting time is preferred by surgeons to ensuring adequate tissue adjustment.
Frozen formulations are available and are thawed at the time of use. Both fibrinogen and thrombin components undergo viral inactivation and reduction steps such as by solvent-detergent [9-10], pasteurization [11], dryheat or vapour-heat treatment [12-13] and nanofiltration [14]. Table 1 summarizes the typical composition of commercial FS. Due to the high protein/fibrinogen content, such products usually have high tensile strength and elasticity [6].

FS can also be prepared from single-donor plasma units by hospital blood banks. In general clinical practices, the plasma donations used as starting materials can be obtained from the patient [autologous] or from a plasma donor [allogeneic]. Various methods of production of the fibrinogen fraction, usually based on precipitation of whole plasma, have been developed [15-19]. Human cryoprecipitate is, in practice, the most usual source of fibrinogen for blood bank FS. It is obtained by thawing a plasma unit at close to $2^{\circ} \mathrm{C}$ to generate the cryoprecipitate, most of the plasma supernatant being subsequently removed by centrifugation. The resulting cryoprecipitate is solubilized at room temperature with some residual cryo-poor plasma, recovered aseptically into a syringe and is used fresh or is frozen until use. Such a process yields 5 to $10 \mathrm{ml}$ of fibrinogen solution from $200 \mathrm{ml}$ of plasma. Some blood banks also use ethanol, ammonium sulfate, or polyethylene glycol precipitation $[15,17-18,20]$. Cryoprecipitation and ammonium sulfate precipitation appears to provide the highest fibrinogen yield, whereas ammonium sulfate precipitation was found to yield a FS with higher tensile strength [21]. Until recently, the thrombin used with single-donor FS was from bovine source, but a trends towards the use of human thrombin is seen [2223].

\subsection{Clinical Use}

FS have been introduced in the early 1980's and are now commonly used in Europe, Japan, and increasingly in the US, in most surgical fields, when a

Table 1: Typical composition of commercial fibrin sealants and origin of components

\begin{tabular}{|l|c|c|}
\hline & Content & Origin \\
\hline Fibrinogen, g/l & $80-120$ & Human plasma \\
\hline Fibronectin, g/l & $5-20$ & Human plasma \\
\hline Factor XIII, IU/ml & $10-30$ & Human plasma \\
\hline Aprotinin, $\mathrm{KIU} / \mathrm{ml}$ & 3000 & Bovine lung \\
\hline Thrombin, UNIH/ml & $4-1000$ & Human plasma \\
\hline $\mathrm{CaCl} 2, \mathrm{mM}$ & $40-60$ & - \\
\hline
\end{tabular}


sealing and hemostatic effect is needed. Various types of clinical applicators have been developed, making endoscopic delivery possible [5]. Several extensive reviews have already described the clinical applications of FS [1, 3, 24-27] which are particularly developed in cardio-vascular surgery, neurosurgery, and orthopedic surgery. Successful end-points in the use of FS include improvement in sealing and hemostasis (e.g. reduction in operative and postoperative blood loss) when using FS compared to a placebo or a procedure considered being "standard of care". Interestingly, both commercial and single-donor FS are used in patients suffering from bleeding disorders to carry out dental extraction procedures, perform orthopedic surgeries, non-orthopedic surgeries and circumcision [7, 28-31], reducing the needs for intravenous substitutive therapy [32]. A recent note by the European Committee for Proprietary Medicinal Products (CPMP) of the European Agency for the Evaluation of Medicinal Products (EMEA) provides guidance on the clinical investigations of FS (CPMP/BPWG/1089/00).

\section{PLATELET GEL}

\subsection{Definition and Properties}

PG are newly developed topical surgical adjuncts [33-34] obtained by combining a platelet-rich blood fraction (platelet concentrate or platelet rich plasma (PRP)), with calcified thrombin [35]. Therefore, there is some similitude in the way FS and PG are obtained, since the formation of the PG mimics the same event of fibrino-formation encountered in FS (Fig 1). However, there are two major differences between FS and PG preparations. First, as the fibrinogen content in the platelet concentrate (fibrinogen physiological content of 2-3 g/l) is less than that in FS (usually more than $80 \mathrm{~g} / 1$ in commercial FS), the strength of the fibrin clot is significantly less in $\mathrm{PG}$, which can therefore not be used for tissue sealing However, second, the activation of platelets by thrombin in PG leads to the release of numerous $\mathrm{GF}$ and other biologically active compounds from the platelet granules, a phenomenom which is not encountered with FS. Those GF confer specific physiological properties to PG. Thay can be used to influence the immediate tissue environment where PG is applied, therefore allowing surgeons to "engineer" both soft and bony tissues and stimulate cell regeneration. This biologically active matrix is therefore increasingly used for the moulding of graft material, for ensuring a secure placement in the tissue defects and for promoting cell migration, vascular invasion, as well as wound healing $[34,36]$. When increasing the strength of $P G$ is needed, then PRP can be mixed with cryoprecipitate, allowing to make a product often refered to as platelet glue. Table 2 summarizes the components required to prepare the various blood-derived biomaterials, and Table 3 compares their characteristics.

\subsection{Platelets: a Biological Reservoir}

Platelets granules are rich in a variety of proteins and other substances known to be crucial to cell differentiation and tissue healing processes, as recently reviewed [35]. Platelets membranes are composed of membrane glycoproteins and membrane receptors of primary agonists such as thrombin, ADP, serotonin, and thromboxane A2. $\alpha$-granules contain coagulation

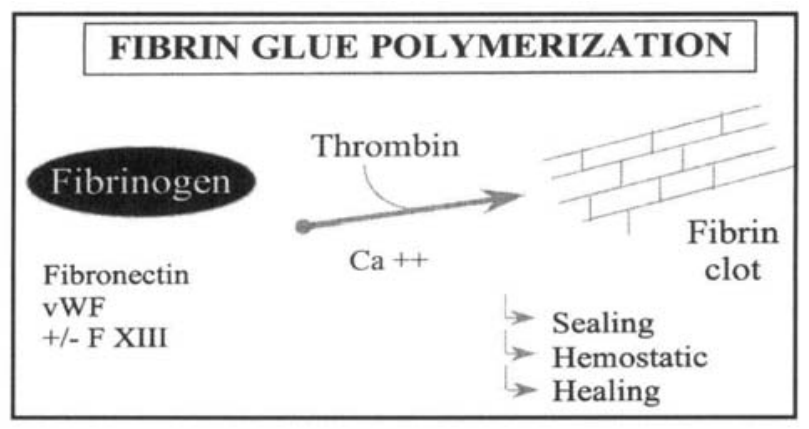

Fig 1. scheme of polymerization of fibrinogen into fibrin by thrombin and calcium ions leading to a fibrin clot with sealing, hemostatic and healing properties.

Table 2: Blood components needed to prepare biomaterials of human origin

\begin{tabular}{|l|c|c|c|c|}
\hline & Commercial FS & Single-donor FS & Platelet gel & Platelet glue \\
\hline Platelet-rich-plasma (PRP) & & & + & + \\
\hline Cryoprecipitate & & + & & + \\
\hline $\begin{array}{l}\text { Single-donor Plasma or } \\
\text { PRP as a source of human thrombin }\end{array}$ & & & + & + \\
\hline Commercial fibrinogen & + & & & \\
\hline Commercial human thrombin & + & & & \\
\hline
\end{tabular}


factors, adhesive proteins, fibrinolytic factors, growth factors, cytokines, chemokines, and regulators of angiogenesis. Dense granules contain ADP/ATP, $\mathrm{Ca} 2+$, serotonin, histamine, catecholamine, and dopamine. Adhesive proteins are abundant in $\alpha$-granules, and include fibrinogen, fibronectin, vitronectin, osteonectin, and thrombospondin-1. During haemostasis, these adhesive proteins bind to platelet receptors, contribute to thrombus growth, and supports hematopoiesis, cell/matrix promotion and wound healing [37-39]. Osteonectin, also secreted by osteoblasts, can form a complex with plasminogen and anchors it to collagen.[40].

$\alpha$-granules are also a reservoir of numerous GF with mitogenic properties [34]. Attention has largely focused on platelet growth factors as key elements explaining the physiological effects of platelets. Those include platelet-derived-growth-factor (PDGF), transforming growth factor $\beta$ (TFG- $\beta$ ), epidermal growth factor (EGF), vascular endothelial growth factor (VEGF), basic fibroblast growth factor (bFGF), and insulin-like growth factor-1 (IGF-1) [35, 41-43]. They, at various degrees, stimulate chemotaxis, cell proliferation and maturation. PDGF is a chemoattractant and stimulates cell proliferation, TGF$\beta$, through its sub-family of bone morphogenetic protein (BMP), impacts bone cell differentiation, IGF1 stimulates bone matrix formation and replication of osteoblasts. Cytokines and chemokines, like RANTES, IL-8, MIP- $1 \alpha$, growth-regulated oncogene- $\beta$, ENA8, MCP-3, and CD40 ligand, are also abundant in $\beta$ granules, and are known to regulate the production of inflammatory molecules by endothelial cells [35]. Tissue factor (TF), which initiates the extrinsic pathway of blood coagulation, regulates angiogenesis, and may contribute to wound healing. Finally, $\beta$ granules also contain factor $V$ that can be activated and play a role in the prothrombinase complex.

\subsection{Mode of Preparation and Quantitative Assessment of Growth Factor Content}

PG are single-donor platelet products from allogeneic or autologous origins; there is no industrial blood-derived PG product available, although topical gels containing recombinant $\mathrm{GF}$ are available [44-45]. The PRP used in PG can be prepared by centrifugation of whole blood donation or by apheresis procedures [46] at hospital blood banks. New collection devices are now available for preparing platelets from small volumes of blood (50 $\mathrm{ml}$ or less) [47], an approach that is especially valuable for preparing autologous $P G$ from the patients themselves in doctors' offices. Platelet fractions (typically a volume of 5 to $10 \mathrm{ml}$ ) are mixed, prior to clinical application, with a similar volume of thrombin to induce clotting of fibrinogen in
5-10 seconds or more [23]. The formation of the platelet gel can be made in the presence of grafting material, either autologous or artificial bones, which then becomes imbedded in the gel, ensuring its secure placement in the tissue defects. Thrombin used so far for the preparation of PG has been from bovine source, but easy-to-use devices to prepare thrombin from single human plasma or platelet donations are now available (e.g. Thrombin Generation Device -TGDßBioStasis, Taiwan). Using such human thrombin preparations avoids the immunologic and infectious risks associated to products from bovine origin and may enhance the release of growth factors [22].

Regardless of the mode of preparation of $P G$, an important parameter is to ensure is a sufficient and reproducible GF content. GF content is in part linked to the platelet concentration in PRP that should be over $10^{11}-10^{12} /$ liter. PDGF-BB, TGF- $\beta 1$, VEGF, and bFGF concentrations in PRP are significantly greater (280\% to $800 \%$ increase) than in whole blood [48]. Mean range of various GF concentrations in PRP preparations, as reported in the literature [22-23, 41 42, 49-51], are summarized in Table 3. Possibly, a higher platelet count might result in higher TGF- $\beta 1$ levels, whereas higher leukocyte count may lead to higher PDGF-AB levels [50]. The factors influencing GF release still require further study [41] to optimize and standardize clinical benefits from the use of PG.

\subsection{Physiological Properties and Clinical Use of PG}

Vascular disruption naturally activates platelets, which then participate in the healing mechanism. Thrombin-induced activation of platelets releases platelet GF that sequester and concentrate in the fibrin gel and are guided to be released on specific sites. Platelet gel initial clinical use has been in wound healing and repair, with the most significant developments in oral and maxillofacial surgery. Today, the use of PG is expanding to other surgical fields, while interest for tissue and cell engineering is growing rapidly. $P G$ is helpful in wound healing because platelets growth factors and cytokines are pivotal in the modulation of the inflammatory, proliferative and remodelling phases of inflammation, a complex process in which a multitude of cellular and humoral components interact to restore a wound defect.

\subsubsection{Cell and tissue engineering}

The rationale behind the use of $P G$ in bone regeneration lies in the fact that the complex series of physiological events that leads to the recruitment, proliferation, and maturation of osteoblasts derived from mesenchymal stem cells (MSC) is promoted by platelet GF [52]. PDGF stimulates osteoblasts replication [53] and TGF- $\beta$ may play a role in fracture 
repair [54] and may stimulate osteogenesis and chondrogenesis [55]. Although studies are still limited, impact of PG or PRP on cell growth and differentiation is being evaluated and the capacity of GF to facilitate growth of cells on scaffold is generating strong interest [56]. PG are now used to provide a directed and concentrated supply of GFs to stimulate migration and maturation of MSC and epithelial cells. The in vitro proliferative and functional activity of human foetal osteoblasts-like cells [57], as well as the migration of MSC [58], was shown to be promoted by human platelet extracts. PRP was shown to induce SSC proliferation in a dose dependent manner, and a $10 \%$ PRP dose was sufficient to induce a marked cell proliferation. Cells expanded with 10\% PRP can mineralize the extracellular matrix once PRP is withdrawn [59]. Bone marrow stromal cells (BMSC) expanded 'ex vivo' are proposed for cell therapy of bone and cartilage defects; FGF2 is particularly efficient at promoting growth and maintening the chondro- osteogenic potential of BMSC [60]. PRP changes cell shape and up-regulated type I collagen at 24 hours in periodontal ligament and osteoblastic cell line [61]. Dedifferentiated adult human articular chondrocytes (AHAC) exhibit differentiation plasticity, which is modulated by growth factors used during monolayer expansion. Platelet GFs, could also help in the identification of AHAC subpopulations with enhanced cartilage repair capacity [62]. Proliferation and matrix synthesis of chondrocytes from rabbit ear cartilage was obtained in the presence of $0.5-1 \%$ concentration of human platelet supernatant, and higher concentration $(10 \%)$ provided conditions for in vitro chondrocyte mass formation [63]. Platelet lysates, when used in place of fetal calf serum, were found to promote growth of primary articular and nasal septal chondrocytes but failed to induce the deposition of typical cartilage matrix components in a threedimensional culture system [64]. Platelets extracts have positive impact on proliferation of human umbilical vein endothelial cell cultures and could therefore possibly stimulate blood vessel formation [48]

\subsubsection{Oral and maxillo-facial surgery}

Autologous PG has been used first by Whitman et al[33] as an alternative to fibrin sealant in reconstructive oral and maxillofacial surgery and for the placement of implants. PG was then shown of benefits for bone graft reconstruction of mandibular continuity defects [34]. PG is used increasingly in oral and maxillofacial surgery to increase the rate of bone deposition and the quality of bone regeneration when augmenting sites prior to or in conjunction with dental implant placement. PG helps in wound healing following tooth extraction, in socket preservation, regeneration of the periodontal unit, and promote bone regeneration and densification of bone graft $[4,34,65-$ 66]. Maturation rate 1.62 to 2.16 times that of grafts without platelet-rich plasma, greater bone density [34], significantly higher amounts of new bone.[36-67] were

Table 3: Comparison of blood-derived biomaterials

\begin{tabular}{|c|c|c|c|c|}
\hline & \multicolumn{4}{|c|}{ Product type } \\
\hline & $\begin{array}{l}\text { Commercial fibrin } \\
\text { sealants }\end{array}$ & $\begin{array}{l}\text { Blood-bank } \\
\text { fibrin sealant }\end{array}$ & Platelet gel & Platelet glue \\
\hline Definition & $\begin{array}{l}\text { Purified } \\
\text { fibrinogen }+ \\
\text { thrombin }\end{array}$ & $\begin{array}{l}\text { Plasma } \\
\text { cryoprecipitate }+ \\
\text { thrombin }\end{array}$ & $\begin{array}{l}\text { Platelet } \\
\text { concentrate }+ \\
\text { thrombin }\end{array}$ & $\begin{array}{l}\text { Platelet } \\
\text { concentrate + } \\
\text { plasma } \\
\text { cryoprecipitate } \\
+ \text { thrombin }\end{array}$ \\
\hline $\begin{array}{l}\text { Pooled or } \\
\text { single-donor } \\
\text { product }\end{array}$ & Pooled & Single-donor & Single-donor & Single-donor \\
\hline Fibrinogen $(\mathrm{g} / \mathrm{l})$ & $>80$ & $15-25$ & $2-3$ & $8-15$ \\
\hline $\begin{array}{l}\text { Aprotinin } \\
\text { (or tranexamic acid) }\end{array}$ & Yes & No & No & No \\
\hline Thrombin origin & Human & Bovine or human & Bovine or human & Bovine or human \\
\hline $\begin{array}{l}\text { Elasticity and } \\
\text { tensile strength }\end{array}$ & ++++ & +++ & 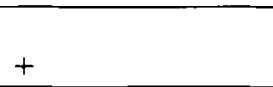 & ++ \\
\hline $\begin{array}{l}\text { Platelet growth } \\
\text { factors }\end{array}$ & No & $\mathrm{No}^{*}$ & Yes & Yes \\
\hline
\end{tabular}


found. Guided bone regeneration using PG seems to be an achievable outcome but controlled clinical studies should be encouraged to establish it and to improve predictability in osseous regenerative procedures with various grafting materials [68]. Experimental and clinical studies found beneficial effects when embedding titanium implants with PG. Increased bone to implant contact and significant enhancement of the quality of bone regeneration at implant sites were found during the early healing phase [69]. An autologous fibrin glue enriched with platelet growth factors (platelet glue) was used successfully with particulate bone grafts for reconstructive purposes [23]. A combination of platelet-rich plasma, bovine porous bone mineral, and guided tissue regeneration was found to be effective for regenerative treatment for mandibular grade II furcation defects [70]. Use of PRP gel placed into residual alveolar bone after extraction to prevent bleeding after dental extraction was evaluated in 40 patients treated with anticoagulant oral therapy; 2 patients reported hemorrhagic complications $(5 \%), 16$ mild bleeding and 22 patients presented with adequate hemostasis. Thus oral surgery in heart surgical patients under oral anticoagulant therapy may be facilitated with PRP gel [71]. Sometimes, experimental studies report controversial findings. No improvement in bone regeneration was found when doing autologous grafts in dogs [72], and no enhancement of bone formation on anorganic bonine bone and on autologous bone grafts in rats [73]. In a three dimensional cell culture system, osteogenic differentiation of marrow derived bone pre-osteoblasts from Spraque-Dawley (SD) rats seeded on porous collagenous carriers was inhibited in a dose dependent manner by PRP [74]. However, bone healing and formation analysis in cranial defects in rabbits showed radiographically that grafts with autogenous bone, xenograft, and xenograft with PRP significantly increase bone density at nearly every point in time evaluated (1 month to 4 months) compared to a nograft control. Xenograft + PRP sites showed a significantly greater increase in bone area at 1,2 , and 4 months than with xenograft alone [75].

\subsubsection{Plastic surgery}

$P G$ are used for improving the healing and regeneration of both soft and bony tissues. Recorded benefits include shorter operative times, less needs for drains and pressure dressings, lower incidences of complications, better consolidations of cancellous bone and comminute fracture segments [76]. Improved aesthetic results, reduced infections and hospital stay were recorded in the treatment of skin and soft tissue losses in recent trauma or chronic pathology [77]. APG appeared to prevent or improve ecchymosis and to a lesser extent oedema after deep-plane rhytidectomy particularly in the early phases of recovery [78]. Benefits were also demonstrated during face-lift, breast augmentations, breast reductions, and neck lift for stopping capillary bleeding involving the creation of a surgical flap [79].

\subsubsection{Orthopedic surgery}

Platelet growth factors are thought to exhibit chemotactic and mitogenic effect on MSC and osteoblasts. PG is increasingly used for the repair of lumbar spinal fusion, mixed with autologous bone or artificial bone to achieve faster bone fusion. Use of PG combined with autograft or artificial graft in posterior fusions or intradiscal fusions has been encouraging [80]. There are also reports of use in bone fractures and total joint replacement. In goats, histological and histomorphometric evaluation revealed that the use of PRP with autologous particulate bone graft strongly enhanced bone healing [81].

\subsubsection{Tendons and cartilage repair}

There is increasing interest in the potential of $P G$ or platelet GFs for the repair of articular cartilage injuries and degeneration, to counterbalance the fact that chondrocytes have limited regenerative and reparative abilities [82]. Injection of calcified autologous PG may be helpful to the reconstruction of ligament and the reattachment of knee articular cartilage, as well as repair of Achille tendon and muscle [35]. Percutaneous injection of platelet was found useful to treat Achilles tendon ruptures in a rat model. Tendon callus strength and stiffness was increased by about $30 \%$ after 1 week, which persisted for as long as 3 weeks after the injection. Greater maturation of the tendon callus was also observed [83].

\subsubsection{Wound healing}

The use of platelet exudates to treat chronic non healing skin ulcers started in the early 1990's. Atri et al. [84] achieved significantly improved results when treating twenty-three patients with 27 skin ulcers which showed no evidence of healing for an average period of 25 weeks and conventional treatment. When using human platelet extracts these ulcers healed completely, $100 \%$ healing occurring in a mean period of about 9.7 weeks. To date, it is established that platelet releasate is more effective than standard care in the treatment of diabetic neuropathic foot ulceration, the effect being greatest for the most severe wounds affecting deeper anatomical structures [85]. Three applications of a combination of platelet extract and cryoprecipitate was also effective in treating chronic foot ulcer in a diabetic patient [86]. Similarly platelet extracts could treat an ankle ulcer of more than 4 years in a thalassemia patient [87]. These data are consistent with the fact that recombinant PDGF used in a topical gel has efficacy in the treatment of refractory chronic 
ulcers [45, 88-89]. Controlled clinical studies comparing the efficacy of recombinant PDGF to autologous platelet extracts, that contain a natural mixture of multiple growth factors, would be of interest.

\section{SAFETY ASPECTS}

\subsection{Human vs Bovine Thrombin}

Since the early 1990 's, the thrombin provided with commercial FS is made from human plasma [3]. However, most thrombin preparations employed for blood-bank FS or PG are from bovine source. As clinical interest increases, attention to the potential risk associated to the use of bovine thrombin, as fibrin and platelet activator, is increasing [90] Two risks have been identified. One is immunologic, associated to the development of anti-bovine factor $\mathrm{V}$ antibodies that cross-react with human factor $\mathrm{V}$ and lead, upon reuse of the product in the same patient, to potentially severe bleeding episodes [91-96]. The other risk is infectious, and is associated to a theoretical risk of transmission of bovine spongiform encephalopathy or variant Creutzfeldt-Jakob disease (vCJD) [97] or to other zoonotic agents from bovine origin. The development of devices to make single-donor human thrombin from single human plasma or platelet donations, alleviates such risks, while allowing to have good production of growth factors [22].

\subsection{Aprotinin}

Most of the current commercial FS preparations are formulated with aprotinin, an antifibrinolytic agent that is used to solubilize the fibrinogen fraction and is expected to slow down the degradation of the fibrin clot by the proteolytic enzymes (e.g. plasmin) of body fluids. Newer products tend not to contain aprotinin, however, in part due to its bovine origin and in part to the fact that its use, which is sometimes debated, needs to be justified by controlled clinical trials. Tranexamic acid has been shown experimentally to be a substitute for aprotinin [98] and it is used in at least one

Table 4: Reported range of growth factors content in platelet gel $(22,23,41,42,49-51)$

\begin{tabular}{|c|c|}
\hline Growth factors & Content $(\mathrm{ng} / \mathrm{ml})$ \\
\hline PDGF-AB & $117-273$ \\
\hline PDGF-BB & $10-14$ \\
\hline TGF- $\beta 1$ & $95-467$ \\
\hline TGF- $\beta 2$ & 0.4 \\
\hline IGF-1 & $69-101$ \\
\hline
\end{tabular}

commercial product. A few allergic cases to aprotinin in FS have been reported.

\subsection{Viral Safety}

Industrial fibrin sealants carry a risk of viral transmission linked to the fact that they are made from large pools of plasma, in a context where one virus infected plasma donation could contaminate a whole batch of product. However, specific production steps are used to reduce the risk of contamination with plasma-borne viruses. Viral safety nets include careful selection of plasma/blood donors, testing of individual plasma donations by immunological tests (HIV, HCV) and antigen (HBV) assays, and nucleic acid tests (NAT) to check for the absence of viral markers [13] and manufacturing processes of both fibrinogen and thrombin have steps to inactivate and eliminate viruses. Those processes must be carefully validated for their ability to reduce the risk of viral transmission. Current procedures in place are very efficient against lipidenveloped viruses but somewhat less against nonenveloped viruses, such as hepatitis A virus and parvovinus $\mathrm{B} 19$.

Blood bank FS and PG made from allogeneic donations are manufactured from single-donor plasma or platelet concentrates. They carry a minimal, statistically small, viral risk if the donation comes from one infected donor. Risks are, however, greatly reduced as such products are not made from pooled donations. Safety relies on proper donor selection and increasingly sensitive viral screening of the donations. Preparing single-donor FS or PG from donations collected from regular donors with well established medical history further decreases the risks. With current standard of selection and testing, HIV, HBV, or HCV viral risks from single plasma or platelet donations is very low, in the order of $1 / 1^{\prime} 000^{\prime} 000$ to $2^{\prime} 000^{\prime} 000$ [99]. The occurrence of emerging infections like West Nile Virus or SARS indicates that constant vigilance (for both pooled products and single-donor products) is needed in the control of the blood supply [100]. To our knowledge, there has been no case of any transmission of viruses by single-donor FS and PG. Obviously, FS and PG made from autologous donations do not pose specific viral risks to the patient.

In conclusion, FS and PG have been shown to be very useful and safe biomaterials for surgical applications. It is likely that the use of allogeneic PG will further develop to make such product available to patients in whom autologous collection is not possible. The trends towards using human thrombin, in place of bovine product, will further continue. Finally, one can predict that research in the use of platelet growth factor extracts "ex vivo" as potential cell engineering tools to induce chondrogenesis and osteogenesis will develop, 
further opening the use of $P G$ in an increasing number of clinical applications.

\section{REFERENCES}

1. Jackson MR, MacPhee MJ, Drohan WN, Alving BM. Fibrin sealant: current and potential clinical applications. Blood Coagul Fibrinolysis 1996;7:73746.

2. Martinowitz U, Saltz R. Fibrin sealant. Curr Opin Hematol 1996;3:395-402.

3. Radosevich M, Goubran HA, Burnouf T. Fibrin sealant: scientific rationale, production methods, properties, and current clinical use. Vox Sang 1997;72:133-43.

4. Max R. Platelet Concentrate:A strategy for Accelerating and Improving Bone Regeneration. David.J.E. ed, "Bone Engineering". em squared incorporated, Toronto, Canada; ; 2000;Chap.41:447453.

5. Marx G. Evolution of fibrin glue applicators. Transfus Med Rev 2003;17:287-98.

6. Duval P, Flan B, Burnouf T, Huart JJ. [Validation of rheological properties of fibrin glue: Biocol-Human Thrombin]. Ann Pharm Fr 1994;52:43-52.

7. Tock B, Drohan W, Hess J, Pusateri A, Holcomb J, MacPhee M. Haemophilia and advanced fibrin sealant technologies. Haemophilia 1998;4:449-55.

8. Burnouf $T$. New trends in plasma fractionation and plasma products. Vox Sang 1994;67 Suppl 3:251-3.

9. Burnouf-Radosevich M, Burnouf T, Huart JJ. Biochemical and physical properties of a solventdetergent-treated fibrin glue. Vox Sang 1990;58:7784.

10. Horowitz B, Prince AM, Horowitz MS, Watklevicz C. Viral safety of solvent-detergent treated blood products. Dev Biol Stand 1993;81:147-61.

11. Hilfenhaus J, Weidmann E. Fibrin glue safety: inactivation of potential viral contaminants by pasteurization of the human plasma components. Arzneimittelforschung 1985;35:1617-9.

12. Burnouf T. Safety aspects in the manufacturing of plasma-derived coagulation factor concentrates. Biologicals 1992;20:91-100.

13. Burnouf T, Radosevich $M$. Reducing the risk of infection from plasma products: specific preventative strategies. Blood Rev 2000;14:94-110.

14. Burnouf T, Radosevich M. Nanofiltration of plasma-derived biopharmaceutical products. Haemophilia 2003;9:24-37.

15. Gammon RR, Avery N, Mintz PD. Fibrin sealant: an evaluation of methods of production and the role of the blood bank. J Long Term Eff Med Implants 1998;8:103-16.

16. Silver FH, Wang MC, Pins GD. Preparation of fibrin glue: a study of chemical and physical methods. J Appl Biomater 1995;6:175-83.

17. Park MS, Cha CI. Biochemical aspects of autologous fibrin glue derived from ammonium sulfate precipitation. Laryngoscope 1993;103:1936.

18. Siedentop KH, Harris DM, Sanchez B. Autologous fibrin tissue adhesive: factors influencing bonding power. Laryngoscope 1988;98:731-3.

19. Weis-Fogh US. Fibrinogen prepared from small blood samples for autologous use in a tissue adhesive system. Eur Surg Res 1988;20:381-9.

20. Siedentop KH, Park JJ, Sanchez B. An autologous fibrin tissue adhesive with greater bonding power. Arch Otolaryngol Head Neck Surg 1995;121:76972.

21. Siedentop KH, Harris DM, Sanchez B. Autologous fibrin tissue adhesive. Laryngoscope 1985;95:1074-6.

22. Su CY, Chiang CC, Lai WF, Lin KW, Burnouf F. PDGF-AB and TGF-sl in platelet gels activated by single-donor human thrombin. Transfusion;in press.

23. Thorn JJ, Sorensen H, Weis-Fogh U, Andersen M. Autologous fibrin glue with growth factors in reconstructive maxillofacial surgery. Int $\mathrm{J}$ Oral Maxillofac Surg 2004;33:95-100.

24. Silver FH, Wang MC, Pins GD. Preparation and use of fibrin glue in surgery. Biomaterials 1995;16:891-903.

25. Komatsu F, Yoshida S. Utility and quality of autologous fresh frozen plasma and autologous fibrin glue for surgical patients. Transfus Sci 1999;21:105-9.

26. Mintz PD, Mayers L, Avery N, Flanagan HL, Burks SG, Spotnitz WD. Fibrin sealant: clinical use and the development of the University of Virginia Tissue Adhesive Center. Ann Clin Lab Sci 2001;31:108-18.

27. Spotnitz WD. Commercial fibrin sealants in surgical care. Am J Surg 2001;182:8S-14S.

28. Bolton-Maggs PH. The management of factor XI deficiency. Haemophilia 1998;4:683-8.

29. Bolton-Maggs PH. Factor XI deficiency and its management. Haemophilia 2000;6 Suppl 1:100-9.

30. Kavakli K. Fibrin glue and clinical impact on haemophilia care. Haemophilia 1999;5:392-6.

31. Martinowitz U, Schulman S, Horoszowski H, Heim $M$. Role of fibrin sealants in surgical procedures on patients with hemostatic disorders. Clin Orthop 1996;328:65-75.

32. Villar A, Jimenez-Yuste V, Quintana M, Hernandez-Navarro F. The use of haemostatic drugs in haemophilia: desmopressin and antifibrinolytic agents. Haemophilia 2002;8:18993. 
33. Whitman DH, Berry RL, Green DM. Platelet gel: an autologous alternative to fibrin glue with applications in oral and maxillofacial surgery. $J$ Oral Maxillofac Surg 1997;55:1294-9.

34. Marx RE, Carlson ER, Eichstaedt RM, Schimmele SR, Strauss JE, Georgeff KR. Platelet-rich plasma: Growth factor enhancement for bone grafts. Oral Surg Oral Med Oral Pathol Oral Radiol Endod 1998;85:638-46.

35. Anitua E, Andia 1, Ardanza B, Nurden P, Nurden AT. Autologous platelets as a source of proteins for healing and tissue regeneration. Thromb Haemost 2004;91:4-15.

36. de Obarrio JJ, Arauz-Dutari JI, Chamberlain TM, Croston A. The use of autologous growth factors in periodontal surgical therapy: platelet gel biotechnology $\nabla$ case reports. Int J Periodontics Restorative Dent 2000;20:486-97.

37. Minor KH, Peterson CB. Plasminogen activator inhibitor type 1 promotes the self-association of vitronectin into complexes exhibiting altered incorporation into the extracellular matrix. J Biol Chem 2002;277:10337-45.

38. Lariviere B, Rouleau M, Picard S, Beaulieu AD. Human plasma fibronectin potentiates the mitogenic activity of platelet-derived growth factor and complements its wound healing effects. Wound Repair Regen 2003;11:79-89.

39. Zhou YQ, Levesque JP, Hatzfeld A, et al. Fibrinogen potentiates the effect of interleukin-3 on early human hematopoietic progenitors. Blood 1993;82:800-6.

40. Kelm RJ, Jr., Swords NA, Orfeo T, Mann KG. Osteonectin in matrix remodeling. A plasminogenosteonectin-collagen complex. J Biol Chem 1994;269:30147-53.

41. Weibrich G, Kleis WK, Hafner G, Hitzler WE. Growth factor levels in platelet-rich plasma and correlations with donor age, sex, and platelet count. J Craniomaxillofac Surg 2002;30:97-102.

42. Weibrich G, Kleis WK, Hafner G. Growth factor levels in the platelet-rich plasma produced by 2 different methods: curasan-type PRP kit versus PCCS PRP system. Int J Oral Maxillofac Implants 2002;17:184-90.

43. Okuda K, Kawase T, Momose M, et al. Plateletrich plasma contains high levels of platelet-derived growth factor and transforming growth factor-beta and modulates the proliferation of periodontally related cells in vitro. J Periodontol 2003;74:849-57.

44. Cohen MA, Eaglstein WH. Recombinant human platelet-derived growth factor gel speeds healing of acute full-thickness punch biopsy wounds. J Am Acad Dermatol 2001;45:857-62.

45. Smiell JM, Wieman TJ, Steed DL, Perry BH, Sampson AR, Schwab BH. Efficacy and safety of becaplermin (recombinant human platelet-derived growth factor-BB) in patients with nonhealing, lower extremity diabetic ulcers: a combined analysis of four randomized studies. Wound Repair Regen 1999;7:335-46.

46. OПNeill EM, Zalewski WM, Eaton LJ, et al. Autologous platelet-rich plasma isolated using the Haemonetics Cell Saver 5 and Haemonetics MCS+ for the preparation of platelet gel. Vox Sang $2001 ; 81: 172-5$.

47. Zimmermann R, Jakubietz R, Jakubietz M, et al. Different preparation methods to obtain platelet components as a source of growth factors for local application. Transfusion 2001;41:1217-24.

48. Lacoste E, Martineau I, Gagnon G. Platelet concentrates: effects of calcium and thrombin on endothelial cell proliferation and growth factor release. J Periodontol 2003;74:1498-507.

49. Weibrich G, Buch RS, Kleis WK, Hafner G, Hitzler WE, Wagner W. Quantification of thrombocyte growth factors in platelet concentrates produced by discontinuous cell separation. Growth Factors 2002;20:93-7.

50. Weibrich G, Kleis WK, Hafner G, Hitzler WE, Wagner W. Comparison of platelet, leukocyte, and growth factor levels in point-of-care plateletenriched plasma, prepared using a modified Curasan kit, with preparations received from a local blood bank. Clin Oral Implants Res 2003; 14:357-62.

51. Weibrich G, Kleis WK, Kunz-Kostomanolakis M, Loos AH, Wagner W. Correlation of platelet concentration in platelet-rich plasma to the extraction method, age, sex, and platelet count of the donor. Int J Oral Maxillofac Implants 2001;16:693-9.

52. Centrella M, Horowitz MC, Wozney JM, McCarthy TL. Transforming growth factor-beta gene family members and bone. Endocr Rev 1994;15:27-39.

53. Yang D, Chen J, Jing Z, Jin D. Platelet-derived growth factor (PDGF)-AA: a self-imposed cytokine in the proliferation of human fetal osteoblasts. Cytokine 2000;12:1271-4.

54. Joyce ME, Terek RM, Jingushi S, Bolander ME. Role of transforming growth factor-beta in fracture repair. Ann N Y Acad Sci 1990;593:107-23.

55. Joyce ME, Roberts AB, Sporn MB, Bolander ME. Transforming growth factor-beta and the initiation of chondrogenesis and osteogenesis in the rat femur. J Cell Biol 1990;110:2195-207.

56. Weiser L, Bhargava M, Attia E, Torzilli PA. Effect of serum and platelet-derived growth factor on chondrocytes grown in collagen gels. Tissue Eng 1999;5:533-44.

57. Slater M, Patava J, Kingham K, Mason RS. 
Involvement of platelets in stimulating osteogenic activity. J Orthop Res 1995;13:655-63.

58. Oprea WE, Karp JM, Hosseini MM, Davies JE. Effect of platelet releasate on bone cell migration and recruitment in vitro. J Craniofac Surg 2003;14:292-300.

59. Lucarelli E, Beccheroni A, Donati D, et al. Plateletderived growth factors enhance proliferation of human stromal stem cells. Biomaterials 2003;24:3095-100.

60. Mastrogiacomo M, Cancedda R, Quarto R. Effect of different growth factors on the chondrogenic potential of human bone marrow stromal cells. Osteoarthritis Cartilage 2001;9 Suppl A:S36-40.

61. Kawase T, Okuda K, Wolff LF, Yoshie H. Plateletrich plasma-derived fibrin clot formation stimulates collagen synthesis in periodontal ligament and osteoblastic cells in vitro. J Periodontol 2003;74:858-64.

62. Barbero A, Ploegert S, Heberer M, Martin I. Plasticity of clonal populations of dedifferentiated adult human articular chondrocytes. Arthritis Rheum 2003;48:1315-25.

63. Yang SY, Ahn ST, Rhie JW, et al. Platelet supernatant promotes proliferation of auricular chondrocytes and formation of chondrocyte mass. Ann Plast Surg 2000;44:405-11.

64. Kaps C, Loch A, Haisch A, et al. Human platelet supernatant promotes proliferation but not differentiation of articular chondrocytes. Med Biol Eng Comput 2002;40:485-90.

65. Tozum TF, Demiralp B. Platelet-rich plasma: a promising innovation in dentistry. J Can Dent Assoc 2003;69:664.

66. Anitua E. The use of plasma-rich growth factors (PRGF) in oral surgery. Pract Proced Aesthet Dent 2001;13:487-93; quiz 487-93.

67. Anitua E. Plasma rich in growth factors: preliminary results of use in the preparation of future sites for implants. Int $J$ Oral Maxillofac Implants 1999;14:529-35.

68. Sanchez AR, Sheridan PJ, Kupp LI. Is platelet-rich plasma the perfect enhancement factor? A current review. Int J Oral Maxillofac Implants 2003;18:93103.

69. Zechner W, Tangl S, Tepper G, et al. Influence of platelet-rich plasma on osseous healing of dental implants: a histologic and histomorphometric study in minipigs. Int $J$ Oral Maxillofac Implants 2003;18:15-22.

70. Lekovic V, Camargo PM, Weinlaender M, Vasilic $\mathrm{N}$, Aleksic Z, Kenney EB. Effectiveness of a combination of platelet-rich plasma, bovine porous bone mineral and guided tissue regeneration in the treatment of mandibular grade II molar furcations in humans. J Clin Periodontol 2003;30:746-51.
71. Della Valle A, Sammartino G, Marenzi G, et al. Prevention of postoperative bleeding in anticoagulated patients undergoing oral surgery: use of platelet-rich plasma gel. $\mathrm{J}$ Oral Maxillofac Surg 2003;61:1275-8.

72. Choi BH, Im CJ, Huh JY, Suh JJ, Lee SH. Effect of platelet-rich plasma on bone regeneration in autogenous bone graft. Int J Oral Maxillofac Surg 2004;33:56-9.

73. Roldan JC, Jepsen S, Miller J, et al. Bone formation in the presence of platelet-rich plasma vs. bone morphogenetic protein-7. Bone 2004;34:80-90.

74. Arpornmaeklong P, Kochel M, Depprich R, Kubler NR, Wurzler KK. Influence of platelet-rich plasma (PRP) on osteogenic differentiation of rat bone marrow stromal cells. An in vitro study. Int $\mathbf{J}$ Oral Maxillofac Surg 2004;33:60-70.

75. Aghaloo TL, Moy PK, Freymiller EG. Evaluation of platelet-rich plasma in combination with anorganic bovine bone in the rabbit cranium: a pilot study. Int J Oral Maxillofac Implants 2004;19:59-65.

76. Bhanot S, Alex JC. Current applications of platelet gels in facial plastic surgery. Facial Plast Surg 2002;18:27-33.

77. Valbonesi M, Giannini G, Migliori F, Dalla Costa $\mathrm{R}$, Galli A. The role of autologous fibrin-platelet glue in plastic surgery: a preliminary report. Int $\mathrm{J}$ Artif Organs 2002;25:334-8.

78. Powell DM, Chang E, Farrior EH. Recovery from deep-plane rhytidectomy following unilateral wound treatment with autologous platelet gel: a pilot study. Arch Facial Plast Surg 2001;3:245-50.

79. Man D, Plosker H, Winland-Brown JE. The use of autologous platelet-rich plasma (platelet gel) and autologous platelet-poor plasma (fibrin glue) in cosmetic surgery. Plast Reconstr Surg 2001;107:229-37; discussion 238-9.

80. Lowery GL, Kulkarni S, Pennisi AE. Use of autologous growth factors in lumbar spinal fusion. Bone 1999;25:47S-50S.

81. Fennis JP, Stoelinga PJ, Jansen JA. Mandibular reconstruction: a histological and histomorphometric study on the use of autogenous scaffolds, particulate cortico-cancellous bone grafts and platelet rich plasma in goats. Int $\mathrm{J}$ Oral Maxillofac Surg 2004;33:48-55.

82. Hickey DG, Frenkel SR, Di Cesare PE. Clinical applications of growth factors for articular cartilage repair. Am J Orthop 2003;32:70-6.

83. Aspenberg $\mathrm{P}$, Virchenko O. Platelet concentrate injection improves Achilles tendon repair in rats. Acta Orthop Scand 2004;75:93-9.

84. Atri SC, Misra J, Bisht D, Misra K. Use of homologous platelet factors in achieving total 
healing of recalcitrant skin ulcers. Surgery 1990;108:508-12.

85. Margolis DJ, Kantor J, Santanna J, Strom BL, Berlin JA. Effectiveness of platelet releasate for the treatment of diabetic neuropathic foot ulcers. Diabetes Care 2001;24:483-8.

86. Tarroni G, Tessarin C, De Silvestro L, et al. [Local therapy with platelet-derived growth factors for chronic diabetic ulcers in haemodialysis patients]. G Ital Nefrol 2002;19:630-3.

87. Gilsanz F, Escalante F, Auray C, Olbes AG. Treatment of leg ulcers in beta-thalassaemia intermedia: use of platelet-derived wound healing factors from the patient $\prod$ s own platelets. $\mathrm{Br} \mathbf{J}$ Haematol 2001;115:710.

88. Kallianinen LK, Hirshberg J, Marchant B, Rees RS. Role of platelet-derived growth factor as an adjunct to surgery in the management of pressure ulcers. Plast Reconstr Surg 2000;106:1243-8.

89. Harrison-Balestra C, Eaglstein WH, Falabela AF, Kirsner RS. Recombinant human platelet-derived growth factor for refractory nondiabetic ulcers: a retrospective series. Dermatol Surg 2002;28:755-9; discussion 759-60.

90. Landesberg R, Moses M, Karpatkin M. Risks of using platelet rich plasma gel. J Oral Maxillofac Surg 1998;56:1116-7.

91. Berruyer M, Amiral J, Ffrench $P$, et al. Immunization by bovine thrombin used with fibrin glue during cardiovascular operations. Development of thrombin and factor $\mathrm{V}$ inhibitors. $\mathrm{J}$ Thorac Cardiovasc Surg 1993; 105:892-7.

92. Banninger $\mathrm{H}$, Hardegger $\mathrm{T}$, Tobler A, et al. Fibrin glue in surgery: frequent development of inhibitors of bovine thrombin and human factor $\mathrm{V} . \mathrm{Br} \mathrm{J}$ Haematol 1993;85:528-32.
93. Israels SJ, Israels ED. Development of antibodies to bovine and human factor $\mathrm{V}$ in two children after exposure to topical bovine thrombin. Am J Pediatr Hematol Oncol 1994;16:249-54.

94. Leroy-Matheron C, Mallat A, Duvoux C, et al. Inhibitor against coagulation factor $\mathrm{V}$ after liver transplantation. Transplantation 1999;68:1054-6.

95. Zehnder JL, Leung LL. Development of antibodies to thrombin and factor $\mathrm{V}$ with recurrent bleeding in a patient exposed to topical bovine thrombin. Blood 1990;76:2011-6.

96. Ortel TL, Mercer MC, Thames EH, Moore KD, Lawson JH. Immunologic impact and clinical outcomes after surgical exposure to bovine thrombin. Ann Surg 2001;233:88-96.

97. Bruce ME, Will RG, Ironside JW, et al. Transmissions to mice indicate that ${ }^{\text {nM new }}$ variant $\prod$ CJD is caused by the BSE agent. Nature 1997;389:498-501.

98. Vankemmel O, de La Taille A, Burnouf T, Rigot JM, Duchene F, Mazeman E. Evaluation of a fibrin sealant free of bovine-derived components in an experimental vas anastomosis study. Urol Int 2000;65:196-9.

99. Dodd RY, Notari EPt, Stramer SL. Current prevalence and incidence of infectious disease markers and estimated window-period risk in the American Red Cross blood donor population. Transfusion 2002;42:975-9.

100. Dodd RY. Emerging infections, transfusion safety, and epidemiology. N Engl J Med 2003;349:12056. 